\title{
The effect of long-term use of intranasal steroids on intraocular pressure
}

\author{
This article was published in the following Dove Press journal: \\ Clinical Ophthalmology \\ 10 June 2016 \\ Number of times this article has been viewed
}

\author{
Ali Șimșek' \\ Cem Bayraktar ${ }^{2}$ \\ Sedat Doğan² \\ Mehmet Karataș ${ }^{2}$ \\ Yasin Sarıkaya ${ }^{2}$ \\ 'Department of Ophthalmology, \\ ${ }^{2}$ Department of Otolaryngology \\ Head and Neck Surgery, Adiyaman \\ University Research and Education \\ Hospital, Adıyaman, Turkey
}

\begin{abstract}
Long-term use of topical nasal steroids (especially older generation steroids) has been shown to elevate intraocular pressure (IOP), but newer intranasal steroids are thought to have a minimal effect on IOP because of their low bioavailability. This study aimed to investigate alterations in IOP with two commonly used intranasal steroids for a 6-month period of time. One-hundred allergic rhinitis patients, divided equally into two groups, used mometasone furoate and fluticasone furoate intranasal steroids for 6 months. IOPs were measured before treatment and repeated at the $3 \mathrm{rd}, 6 \mathrm{th}, 12 \mathrm{th}$, and 24th weeks of treatment. The IOPs of the groups were then compared. No statistically significant alteration was observed between the groups during the treatment time period. It was found that new generation intranasal steroids can be used safely, and there may not be an increased risk of IOP elevation in prolonged use in normal healthy people.
\end{abstract}

Keywords: intraocular pressure, nasal steroids, prolonged use, allergic rhinitis

\section{Introduction}

Topical nasal steroids are widely used by otolaryngologists to treat allergic rhinitis (AR) patients for a long period of time. ${ }^{1}$ Prolonged use of these drugs can cause some adverse effects on eyes. The literature has reported posterior subcapsular cataract and elevated intraocular pressure (IOP) levels with long-term use of intranasal steroids. ${ }^{2,3}$

IOP has a circadian rhythm, and one study has described a relationship between plasma cortisol levels and IOP fluctuation. ${ }^{4}$ IOP can vary with age, systemic/local factors, and medications. ${ }^{5}$ Although systemic, topical or ophthalmic use of steroids can increase IOP, the effect of intranasal use of steroids on IOP is controversial. ${ }^{3,6}$

This study aimed to investigate IOP alterations in AR patients using two common intranasal steroids for a 6-month period of time.

\section{Materials and methods}

One-hundred patients (41 women, 59 men; mean age \pm standard deviation: 47.88 \pm 18.90 ) were enrolled in this study. All patients were diagnosed with AR as defined by the Allergic Rhinitis and Its Impact on Asthma (ARIA) study, ${ }^{7}$ and all of the patients were treated with intranasal steroid sprays. Half of the patients (50 subjects) used mometasone furoate nasal spray (Nasonex, MSD, Merck \& Co., Inc., Whitehouse Station, NJ, USA; $200 \mu \mathrm{g} /$ day) and the other half (50 subjects) used fluticasone furoate nasal spray (Avamys, GlaxoSmithKline, London, UK; $110 \mu \mathrm{g} /$ day). Each patient underwent a thorough otolaryngological and ophthalmological examination before treatment. Fundoscopic examinations were performed on all 100 subjects, and IOPs were measured using Goldmann Applanation Tonometry. All eye measurements were carried 
out by the same ophthalmologist, all the measurements were performed at the same time between $1 \mathrm{pm}$ and $2 \mathrm{pm}$, and IOP was measured at the $3 \mathrm{rd}, 6 \mathrm{th}, 12 \mathrm{th}$, and 24 th weeks of treatment for each patient. This study conforms to the tenets of the Declaration of Helsinki and it was approved by the Ethics Committee of Adıyaman University, and written informed patient consent was obtained. Exclusion criteria for study participation were additional nasal illnesses, such as polyposis or chronic sinusitis, ophthalmic or systemic disorders, previous steroid use (topical/systemic), known ocular hypertension or glaucoma patients, and under the age of 18 .

Data analysis was performed using SPSS 15.0 for Windows (SPSS Inc., Chicago, IL, USA). Age distribution was not normal, and Mann-Whitney $U$-test was used for comparison of both groups. IOP measurements' data distribution was normal, Student's $t$-test was used for paired comparisons between preoperative measurement and other time intervals. A $P$-value $<0.05$ was considered statistically significant.

\section{Results}

One-hundred patients (50 subjects in each group) were included in this prospective study. The mean age in the fluticasone furoate and the mometasone furoate groups was $47.48 \pm 19.16$ and $48.28 \pm 18.83$, respectively. No statistically significant differences in age averages and sex distribution were found between the groups $(P>0.05)$ (Table 1).

Averages for the IOP for the right and left eyes for the initial, 3rd, 6th, 12th, and 24th weeks of treatment are shown in Tables 2 and 3 for both steroid groups. Although some IOP fluctuations were observed, no statistically significant differences were found on the paired comparisons of the initial and the four time measurements $(P>0.05)$.

\section{Discussion}

Intranasal steroids are used to effectively treat perennial and seasonal AR, and they consist of two generations of steroids. First-generation intranasal steroids (budesonide, beclomethasone dipropionate, and triamcinolone acetonide) have more systemic bioavailability in comparison to second-generation intranasal steroids (mometasone furoate, fluticasone propionate, and fluticasone furoate). While systemic bioavailability can increase up to $49 \%$ with older generation steroids, it is $<1 \%$ for fluticasone and mometasone furoate. ${ }^{8}$ Absorption from nasal and gastrointestinal mucosa are the ways that intranasal steroids can enter the blood stream. Direct pass occurs via nasal mucosa without first-pass metabolism, so this can excessively injure the end organs. On the other hand, steroids absorbed from the gastrointestinal system undergo degradation in the liver, so less active metabolites can reach the end organs. ${ }^{9}$ It has been reported that the amount of steroids absorbed from the nasal passages is minimal in comparison to the amount of steroids absorbed from the gastrointestinal tract. ${ }^{8}$ However, inflammation is present in baseline rhinitis and this may cause a high absorption of steroids from nasal mucosa. ${ }^{10}$

IOP depends on humor aqueous secretion from the ciliary process and its excretion to episcleral veins via trabecular meshwork. However, both formation and excretion are balanced. ${ }^{5}$ There are some theories as to how steroid-induced IOP elevation occurs. Altered electrolyte imbalance, an increment in trabecular meshwork mucopolysaccharides, steroid-induced vasoconstriction in episcleral veins, and actin remodeling in trabecular meshwork can all lead to elevated IOP. ${ }^{9,11}$ It is also important to note that trabecular cells contain steroid receptors and this can be associated with resistance to the outflow of humor aqueous. ${ }^{9,12-14}$

The literature has reported contradictory findings regarding inhaler/nasal steroid usage and IOP. The first report about IOP and inhaled steroids was published in 1993 by Dreyer. ${ }^{15}$ Glaucoma was reported in three patients during treatment with inhaled beclomethasone dipropionate. Opatowsky et $\mathrm{al}^{3}$ also showed IOP elevation in three cases with inhaled and/or nasal beclomethasone dipropionate treatment. They concluded that this effect was reversible with elimination of the drugs. Moreover, Öztürk et $\mathrm{al}^{13}$ followed-up patients who underwent endoscopic sinus surgery and who used budesonide and beclomethasone dipropionate on average for 8.8 months, and no statistically significant increase in

Table I Age and sex distribution of groups

\begin{tabular}{lllll}
\hline & Fluticasone group & Mometasone group & Total & P-value \\
\hline Number of patients & 50 & 50 & 100 & $47.88 \pm 18.90$ \\
Age (mean \pm standard deviation) & $47.48 \pm 19.16$ & $48.28 \pm 18.83$ & & $0.79 *$ \\
Sex (\%) & & & 41.0 & $0.83^{*}$ \\
$\quad$ Female & 42.0 & 40.0 & 59.0 & \\
Male & 58.0 & 60.0 & & \\
\hline
\end{tabular}

Notes: ${ }^{*}$ Chi-square test, $*$ Mann-Whitney $U$-test. 
Table 2 Paired comparisons of intraocular pressure preoperatively and at other time intervals in fluticasone group for both eyes

\begin{tabular}{|c|c|c|}
\hline Comparisons & $\begin{array}{l}\text { Mean } \pm \text { standard } \\
\text { deviation }\end{array}$ & $P$-value ${ }^{*}$ \\
\hline \multicolumn{3}{|l|}{ Right eye } \\
\hline Preoperative - & $14.28 \pm 1.60$ & 0.90 \\
\hline $\begin{array}{l}\text { 3rd week } \\
\text { Preoperative - }\end{array}$ & $\begin{array}{l}14.26 \pm 1.62 \\
14.28 \pm 1.60\end{array}$ & 0.78 \\
\hline $\begin{array}{l}\text { 6th week } \\
\text { Preoperative - }\end{array}$ & $\begin{array}{l}14.24 \pm 1.62 \\
14.28 \pm 1.60\end{array}$ & 0.88 \\
\hline $\begin{array}{l}\text { I2th week } \\
\text { Preoperative - }\end{array}$ & $\begin{array}{l}14.26 \pm 1.56 \\
14.28 \pm 1.60\end{array}$ & 0.69 \\
\hline 24th week & $14.34 \pm 1.58$ & \\
\hline \multicolumn{3}{|l|}{ Left eye } \\
\hline Preoperative - & $13.80 \pm 1.70$ & 0.15 \\
\hline 3 rd week & $13.96 \pm 1.45$ & \\
\hline Preoperative - & $13.80 \pm 1.70$ & 0.45 \\
\hline $\begin{array}{l}\text { 6th week } \\
\text { Preoperative - }\end{array}$ & $\begin{array}{l}13.88 \pm 1.39 \\
\mid 3.80 \pm 1.70\end{array}$ & 0.84 \\
\hline I2th week & $|3.78 \pm| .5 \mid$ & \\
\hline Preoperative - & $13.80 \pm 1.70$ & 0.33 \\
\hline 24th week & $13.92 \pm 1.52$ & \\
\hline
\end{tabular}

Note: * Student's $t$-test.

IOP was observed. Man et $\mathrm{al}^{16}$ performed a similar study in which patients used fluticasone propionate for 6 weeks postoperatively, and neither IOP elevation nor posterior subcapsular cataract formation was observed. In a doubleblind prospective experimental study, the effect of nasal steroids (fluticasone propionate, mometasone furoate, and beclomethasone dipropionate) on the IOPs of patients with

Table 3 Paired comparisons of intraocular pressure preoperatively and at other time intervals in mometasone group for both eyes

\begin{tabular}{|c|c|c|}
\hline Comparisons & $\begin{array}{l}\text { Mean } \pm \text { standard } \\
\text { deviation }\end{array}$ & $P$-value* \\
\hline \multicolumn{3}{|l|}{ Right eye } \\
\hline Preoperative - & $|3.66 \pm 2.0|$ & 0.14 \\
\hline 3rd week & $13.80 \pm 1.98$ & \\
\hline Preoperative - & $13.66 \pm 2.0 \mid$ & 0.39 \\
\hline 6th week & $13.74 \pm \mid .84$ & \\
\hline Preoperative - & $13.66 \pm 2.0 \mid$ & 0.44 \\
\hline 12th week & $13.76 \pm 1.70$ & \\
\hline Preoperative - & $|3.66 \pm 2.0|$ & 0.59 \\
\hline 24th week & $13.72 \pm 1.76$ & \\
\hline \multicolumn{3}{|l|}{ Left eye } \\
\hline Preoperative - & $|3.28 \pm| .88$ & 0.42 \\
\hline $3 r d$ week & $13.32 \pm 1.89$ & \\
\hline Preoperative - & $13.28 \pm 1.88$ & 0.37 \\
\hline 6th week & $13.34 \pm 1.89$ & \\
\hline Preoperative - & $13.28 \pm 1.88$ & 0.42 \\
\hline I2th week & $13.36 \pm 1.74$ & \\
\hline Preoperative - & $13.28 \pm 1.88$ & 0.37 \\
\hline 24th week & $13.22 \pm 1.83$ & \\
\hline
\end{tabular}

Note: *Student's t-test. rhinitis was studied for 1 year; significant alteration in the IOPs, which were found to be within normal limits, was not observed. ${ }^{5}$ In our study, we encountered similar findings; no statistically significant elevation was observed in the IOP parameters during the 6-month period with fluticasone and mometasone nasal steroids.

Steroid-induced IOP elevation can occur in patients with risk factors, including primary open angle glaucoma, diabetes mellitus, high myopia, connective tissue disorders, and a first degree relative with primary open angle glaucoma. ${ }^{9,17}$

Although patients with ocular hypertension and glaucoma have a tendency for IOP increment when using nasal steroids, contradictory findings have also been reported in this patient group. Garbe et $\mathrm{al}^{12}$ investigated the effect of normal and high dosage inhaler steroid treatment on IOP in glaucomatous and ocular hypertensive patients, and they suggested that only high dose administration of these steroids for 3 or more months was associated with ocular hypertension and glaucoma.

In a small placebo-controlled, prospective, randomized trial, 19 patients, with primary open angle glaucoma or ocular hypertension, used beclomethasone dipropionate nasal spray for 6 weeks, and the authors concluded that no statistically significant increment was observed in IOP when compared with the placebo group. ${ }^{10}$

The only study that found detrimental effects of nasal steroids was by Bui et al, ${ }^{14}$ and they stated that discontinuing nasal steroids revealed a statistically significant reduction in IOP in patients with glaucoma and ocular hypertension (12 patients, eleven with glaucoma and one with ocular hypertension). While they concluded that nasal steroids might elevate IOP, the patients in their study used different types of nasal steroids (both first- and second-generation steroids), and measurements were not selectively performed for each type of steroid.

As a result of our study, we did not observe IOP increment with prolonged use of mometasone furoate and fluticasone furoate nasal sprays during 6-month follow-up. We think that there may not be a risk for increased IOP in healthy subjects.

\section{Conclusion}

New generation intranasal steroids can be used safely with $<1 \%$ systemic bioavailability in normal healthy people. Although close follow-up is recommended for at-risk patients, this treatment recommendation may change if wider patient group studies examine the use of new generation nasal steroids in the future. 


\section{Disclosure}

The authors report no conflicts of interest in this work.

\section{References}

1. LaForce C, Journeay GE, Miller SD, et al. Ocular safety of fluticasone furoate nasal spray in patients with perennial allergic rhinitis: a 2-year study. Ann Allergy Asthma Immunol. 2013;111(1):45-50.

2. Liu A, Manche EE. Bilateral posterior subcapsular cataracts associated with long-term intranasal steroid use. J Cataract Refract Surg. 2011; 37(8):1555-1558.

3. Opatowsky I, Feldman RM, Gross R, Feldman ST. Intraocular pressure elevation associated with inhalation and nasal corticosteroids. Ophthalmology. 1995;102(2):177-179.

4. Kersey JP, Broadway DC. Corticosteroid-induced glaucoma: a review of the literature. Eye (Lond). 2006;20(4):407-416.

5. Bross-Soriano D, Hanenberg-Milver C, Schimelmitz-ldi J, ArrietaGomez JR, Astorga del Toro R, Bravo-Escobar G. Effects of three nasal topical steroids in the intraocular pressure compartment. Otolaryngol Head Neck Surg. 2004;130(2):187-191.

6. Spiliotopoulos C, Mastronikolis NS, Petropoulos IK, Mela EK, Goumas PD, Gartaganis SP. The effect of nasal steroid administration on intraocular pressure. Ear Nose Throat J. 2007;86(7):394-395.

7. Bousquet J, Van Cauwenberge P, Khaltaev N; Aria Workshop Group; World Health Organization. Allergic rhinitis and its impact on asthma. J Allergy Clin Immunol. 2001;108(5 Suppl):S147-S334.

8. Benninger MS, Ahmad N, Marple BF. The safety of intranasal steroids. Otolaryngol Head Neck Surg. 2003;129(6):739-750.
9. Bergmann J, Witmer MT, Slonim CB. The relationship of intranasal steroids to intraocular pressure. Curr Allergy Asthma Rep. 2009;9(4): 311-315.

10. Yuen D, Buys YM, Jin YP, Alasbali T, Trope GE. Effect of beclomethasone nasal spray on intraocular pressure in ocular hypertension or controlled glaucoma. J Glaucoma. 2013;22(2):84-87.

11. Clark AF, Wilson K, McCartney MD, Miggans ST, Kunkle M, Howe W. Glucocorticoid-induced formation of cross-linked actin networks in cultured human trabecular meshwork cells. Invest Ophthalmol Vis Sci. 1994;35(1):281-294.

12. Garbe E, LeLorier J, Boivin JF, Suissa S. Inhaled and nasal glucocorticoids and the risks of ocular hypertension or open-angle glaucoma. JAMA. 1997;277(9):722-727.

13. Ozturk F, Yuceturk AV, Kurt E, Unlü HH, Ilker SS. Evaluation of intraocular pressure and cataract formation following the long-term use of nasal corticosteroids. Ear Nose Throat J. 1998;77(10):846-848, 850-851.

14. Bui CM, Chen H, Shyr Y, Joos KM. Discontinuing nasal steroids might lower intraocular pressure in glaucoma. J Allergy Clin Immunol. 2005;116(5):1042-1047.

15. Dreyer EB. Inhaled steroid use and glaucoma. N Engl J Med. 1993; 9;329(24): 1822.

16. Man LX, Farhood Z, Luong A, et al. The effect of intranasal fluticasone propionate irrigations on salivary cortisol, intraocular pressure, and posterior subcapsular cataracts in postsurgical chronic rhinosinusitis patients. Int Forum Allergy Rhinol. 2013;3(12):953-957.

17. Jones R 3rd, Rhee DJ. Corticosteroid-induced ocular hypertension and glaucoma: a brief review and update of the literature. Curr Opin Ophthalmol. 2006;17(2):163-167.
Clinical Ophthalmology

\section{Publish your work in this journal}

Clinical Ophthalmology is an international, peer-reviewed journal covering all subspecialties within ophthalmology. Key topics include: Optometry; Visual science; Pharmacology and drug therapy in eye diseases; Basic Sciences; Primary and Secondary eye care; Patient Safety and Quality of Care Improvements. This journal is indexed on Submit your manuscript here: http://www.dovepress.com/clinical-ophthalmology-journal

\section{Dovepress}

PubMed Central and CAS, and is the official journal of The Society of Clinical Ophthalmology (SCO). The manuscript management system is completely online and includes a very quick and fair peer-review system, which is all easy to use. Visit http://www.dovepress.com/ testimonials.php to read real quotes from published authors. 